\title{
Testing the Monetary Model for Exchange Rate Determination in South Africa: Evidence from 101 Years of Data
}

\author{
Riané de Bruyn', Rangan Gupta' \& Lardo Stander'
}

\begin{abstract}
Evidence in favor of the monetary model of exchange rate determination for the South African Rand is, at best, mixed. A co-integrating relationship between the nominal exchange rate and monetary fundamentals forms the basis of the monetary model. With the econometric literature suggesting that the span of the data, not the frequency, determines the power of the co-integration tests and the studies on South Africa primarily using short-span data from the post-Bretton Woods era, we decided to test the long-run monetary model of exchange rate determination for the South African Rand relative to the US Dollar using annual data from 1910 - 2010. The results provide some support for the monetary model in that long-run co-integration is found between the nominal exchange rate and the output and money supply deviations. However, the theoretical restrictions required by the monetary model are rejected. A vector error-correction model identifies both the nominal exchange rate and the monetary fundamentals as the channel for the adjustment process of deviations from the long-run equilibrium exchange rate. A subsequent comparison of nominal exchange rate forecasts based on the monetary model with those of the random walk model suggests that the forecasting performance of the monetary model is superior.
\end{abstract}

KEY WORDS: $\quad$ nominal exchange rate, monetary model, long-span data, forecasting

JEL Classification: C22, C32, C53, F31, F47

${ }^{1}$ University of Pretoria, South Africa

\section{Introduction}

This paper sets out to test whether a simple form of the long-run exchange rate model for South Africa (relative to the United States of America (US)) based on the monetary fundamentals of relative money supply and relative output holds for a century of data. The intuition underlying the simple monetary model is quite attractive analytically: a country's price level is determined by the supply and demand for money in that country, and the price level in different countries

Correspondence concerning this article should be addressed to: Rangan Gupta, Department of Economics, University of Pretoria, Pretoria 0002, SOUTH AFRICA, e-mail: rangan.gupta@up.ac.za should be the same when expressed in a common currency. This model serves as a benchmark evaluation tool of the long-run nominal exchange rates between two or more currencies.

The analytical tractability of the simple monetary model of exchange rate determination is interesting in the South African context, where empirical results in favor of the model remain mixed at best (Hassan \& Simione, 2011). Earlier studies by Aron, Elbadawi and Kahn (1997), Casteleijn (1999), Jonsson (1999), Moll (1999; 2000), as detailed in Nell (2003), and the more recent study by Ziramba (2007) tend to find no longrun relationship between nominal exchange rates, money supply and income, which is the essence of the 
simple monetary model. In contrast, Chinn (1999), Brink and Koekemoer (2000), Sichei, Gebreselasie and Akanbi (2005), Dube (2008) provide empirical support in favor of the monetary model, but only after modifying the simple monetary model to allow for a trend. However, the inclusion of the trend and other variables such as commodity prices, stock prices and current account is often viewed as testing for a weaker version of the long-run monetary model (Rapach \& Wohar, 2002). These studies use short spans of data and typically focus only on the post-Bretton Woods era when testing for a long-run relationship between nominal exchange rates and monetary fundamentals.

Support for the long-run monetary model in more recent studies has highlighted the use of longer spans of data in a variety of testing procedures. Rapach and Wohar (2002) present favorable results for the monetary model using a century of data and corroborate these findings with results based on panel data (Rapach \& Wohar, 2004). As shown by Shiller and Perron (1985), Hakkio and Rush (1991) and Otero and Smith (2000) in Rapach and Wohar (2004), the span of the data, not the frequency, determines the power of the unit root and co-integration tests, which concludes the existence of a long-run relationship between nominal exchange rates and a set of monetary fundamentals.

Purchasing power parity (PPP) is a key component of the simple monetary model, with long-run PPP suggesting a stable long-run relationship between nominal exchange rates and relative price levels between different countries. Empirical support for such a relationship in South Africa and in general, using data from the modern float, is scant. Evidence of PPP in South Africa is only observed for the modern float era when one allows for nonlinearity (Lacerda, Fedderke \& Haines, 2010; Mokoena, 2007), half-life definitions (Mokoena, Gupta \& van Eyden, 2009a), Bayesian unit root tests (Mokoena, Gupta \& van Eyden, 2009b) and long memory (Mokoena, Gupta \& van Eyden, 2009c). Again, the lack of empirical support for such a long-run relationship can be attributed to the low power of standard tests for short samples covering the modern float. Because PPP is an important assumption in the monetary model, the mixed South African evidence of the monetary model is not surprising, as many studies find it difficult to obtain co-integration between nominal exchange rates and monetary fundamentals during the post-Bretton Woods era.
Thus, in this paper, we decided to revisit the applicability of the monetary model for determination of the South African Rand and US Dollar exchange rate using a data set that comprises 101 years of data. When using longer spans of data, some of the earlier problems, such as not finding a co-integrating relationship between nominal exchange rates and a set of monetary fundamentals, related to testing the validity of the monetary model are likely to be overcome. Hence, these results could possibly provide an explanation of the mixed evidence observed for the validity of the monetary model in South Africa. To account for possible structural instability over the longer sample period, it is further assumed that the dynamic processes related to nominal exchange rates, relative money supply and relative output are relatively stable. This critical stability assumption is equivalent to finding a long-run co-integrating relationship between nominal exchange rates, relative money supply and relative output. The potential problem of structural instability always exists when using long spans of data. However, following the PPP literature that utilizes long spans of data, we assume that the dynamics are relatively stable over the sample period (Rapach \& Wohar, 2004). Moreover, when we tested PPP for the Rand-Dollar real exchange rate using standard unit root tests, we found that the real exchange rate was trend stationary. Furthermore, the CUSUM test revealed a stable co-integrating relationship between the exchange rate and the differentials of the money and output measures. The stability was also illustrated by the SupF test proposed by Andrews (1993) and Andrews and Ploberger (1994). The results are not included here but are available from the authors upon request.

The testing procedure in this paper follows the methodology and results reported by Rapach and Wohar (2002), where the authors tested a long-run exchange rate monetary model with a sample of 14 developed countries using a century of data. Based on the support for the simple long-run monetary model, two further aspects are investigated. A vector-error correction model (VECM) is estimated to analyze the adjustment process through which the long-run equilibrium exchange rate based on monetary fundamentals holds. Then, an out-of-sample exchange rate forecast from a random walk model is compared with those from a model based on monetary fundamentals. 
The rest of the paper is organized as follows: Section 2 describes the methodology used in the empirical analysis. Section 3 provides the empirical results for both the monetary model and the VECM. Section 4 details the forecasting comparison between the simple monetary model and a random walk model with drift. Section 5 contains some concluding remarks.

\section{The empirical methodology}

As with all other exchange rate models that attempt to analyze and understand the underlying factors driving exchange rate behavior, the simple monetary model analyzes the specific relationship of the nominal exchange rate with the difference between the foreign and domestic money supply and the difference between foreign and domestic real gross domestic product (GDP).

In this analysis, the US is denoted as the domestic country, and SA is denoted as the foreign country.

There are three basic relationships contained in the standard monetary model: money market equilibrium, PPP and uncovered interest parity (UIP).

The basic money demand functions for both foreign and domestic countries, which are assumed to be stable because the focus is on the long-run equilibrium relationship, are derived from the standard LM-curve representation:

$$
\frac{M_{t}}{P_{t}}=L\left(Y_{t}, I_{t}\right)
$$

where $M_{t}, P_{t}, Y_{t}, I_{t}$ are the nominal money supply, the price level, the real output and the nominal interest rate, respectively. All variables are stated at time $t$, and $L$ is a real money demand function.

Rewriting (1) in its log-form yields the following equations (where foreign variables are denoted with an ${ }^{*}$ :

$\log M_{t}-\log P_{t}=\beta_{1} \log Y_{t}-\beta_{2} \log I_{t}$

$\log M_{t}^{*}-\log P_{t}^{*}=\beta_{1} \log Y_{t}^{*}-\beta_{2} \log I_{t}^{*}$

where $\beta_{1}>0, \beta_{2}<0$, represent the money demand elasticity parameters with respect to output and interest rate and are assumed to be identical for both domestic and foreign countries. Now, let $m \equiv \log M_{t}$, $p \equiv \log P_{t}, y \equiv \log Y_{t}$ and $I=1+i$. We thus obtain $m_{t}-p_{t}=\beta_{1} y_{t}-\beta_{2} i_{t}$

$m_{t}^{*}-p_{t}^{*}=\beta_{1} y_{t}^{*}-\beta_{2} i_{t}^{*}$

where (4) and (5) describe the domestic (US) and foreign (SA) money market equilibrium conditions, respectively. Now, PPP is assumed to hold. Therefore, the standard PPP relation is presented by the following equation:

$P_{t}^{*}=\varepsilon_{t} P_{t}$,

with $P_{t}^{*}$ denoting foreign country prices and $\varepsilon_{t}$ denoting the nominal exchange rate expressed in the number of foreign currency units per unit of domestic currency. This equation can then be rewritten in its log-form as:

$\log \varepsilon_{t}=\log P_{t}^{*}-\log P_{t}$.

Letting $e_{t} \equiv \log \varepsilon_{t}, p_{t}^{*} \equiv \log P_{t}^{*}$ and $p_{t} \equiv \log P_{t}$, we have:

$e_{t}=p_{t}^{*}-p_{t}$

with $e_{t}$ being the nominal exchange rate measured in foreign currency to domestic currency.

Solving (4) and (5) for $p_{t}$ and $p_{t}^{*}$ and substituting the results into (6) yields

$e_{t}=\left(m_{t}^{*}-m_{t}\right)-\beta_{1}\left(y_{t}^{*}-y_{t}\right)+\beta_{2}\left(i_{t}^{*}-i_{t}\right)$

Assuming the UIP, which equates the expected change in the nominal exchange rate with the interest rate differential between the foreign and domestic countries, is typical in the simple monetary model. It is noted that the assumption of UIP typically only holds for highincome countries over long horizons and between currencies that are traded in developed and internationally integrated financial markets. Chinn and Meredith (2005) and Hassan and Simione (2011) present further details. Evidence of the UIP for South Africa has been provided by Kryshko (2006), based on a nonparametric co-integration approach that allows for nonlinearity in the short-run dynamics. Similar results were also obtained by Lacerda, Fedderke and Haines (2010) when allowing for regime switching based on a Markov-Switching VECM. When we used standard 
parametric unit root tests on the Treasury bill rate differential between South Africa and the US using annual data available over the longest possible period of 1936-2010, we found the differential to be trend stationary, suggesting that the UIP holds for the South African and US short-term interest rate differential. More formally,

$i_{t}^{*}-i_{t}=E\left(\Delta e_{t+1} \mid I_{t}\right)$

with $E($.$) as the expected value of the change in the$ future nominal exchange rate based on information in the current period. It is clear that if $e_{t}$ is $I(0)$ or $I(1)$, then $\Delta e_{t+1}$ is zero in the steady state. This can be explained as follows:

When the exchange rate is $I(0)$, then we have: $e_{t+1}=u_{t+1}, u_{t+1} \sim N\left(0, \sigma_{u}^{2}\right)$.

And if the exchange rate is $I(1)$, then we have: $e_{t+1}=e_{t}+u_{t+1}, u_{t+1} \sim N\left(0, \sigma_{u}^{2}\right)$ and $\Delta e_{t+1}=u_{t+1}$

Given this, in long-run equilibrium or in steady-state, $\Delta e_{t+1}=0$ because it takes the value equal to the unconditional mean of $u_{t+1}$. It must, however, be noted that the crucial assumption here is that the error term $u$ is assumed to be a white-noise process with zero mean. As indicated by one of the referees, stationarity can also be obtained with an ARMA error structure (Ahking \& Miller, 2004). Hence, our assumption of the error structure is a restrictive one but follows Rapach and Wohar (2002). Furthermore, following Walsh (2003) under rational expectations, we can write the actual exchange rate at $t+1$ as equal to the expectation of the future exchange rate plus a forecast error $u_{t}$ uncorrelated with $E_{t}\left(e_{t+1}\right)$ $: e_{t+1}=E_{t}\left(e_{t+1}\right)+u_{t+1}$, where $u$ is a mean zero forecast error. If the exchange rate is a random walk, which we show through the unit root tests carried out below, then $E_{t}\left(e_{t+1}\right)=e_{t}$, which implies that $e_{t+1}=e_{t}+u_{t+1}$ and that, in steady-state, $\Delta e_{t+1}=0$. Similar to the concerns raised by the referee, Walsh (2003) also discusses a situation where there could be factors such as risk premia that would lead to divergences between the real returns in the two countries. In the equation for the uncovered interest rate parity condition, $s_{t+1}-s_{t}=i_{t}-i_{t}^{*}+v_{t}$, the error term $v$ is not merely the zero mean forecast errors, but it also contains the risk premia.

This assumption implies that $i_{t}^{*}=i_{t}$, which reduces (7) to $e_{t}=\left(m_{t}^{*}-m_{t}\right)-\beta_{1}\left(y_{t}^{*}-y_{t}\right)$.

This is the basic form of the simple monetary model that forms the basis of the analysis in this paper.

An additional restriction, imposed by Mark (1995) and Mark and Sul (2001), is applied in letting $\beta_{1}=1$ in (9). This further reduction yields the testable equation that constitutes the bulk of the empirical testing in this paper:

$e_{t}=\left(m_{t}^{*}-m_{t}\right)-\left(y_{t}^{*}-y_{t}\right)$

The test for stability of the long-run model depends heavily on the assumption that there will be a longrun co-integrating relationship between the nominal exchange rate, the relative money supply differential and the relative real output differential (Rapach \& Wohar, 2002). First, the integration properties of these three components are tested using unit root tests from $\mathrm{Ng}$ and Perron (2001). These tests have good size and power. If $e_{t} \sim I(1)$, then either one or both of $m_{t}^{*}-m_{t}$ and $y_{t}^{*}-y_{t}$ must also be $I(1)$ and neither can be integrated at an order greater than one.

When $e_{t}, y_{t}^{*}-y_{t}, m_{t}^{*}-m_{t} \sim I(1)$, the long-run monetary model will only hold if these three variables are co-integrated. The co-integration relationship to be estimated is

$e_{t}=\beta_{0}+\beta_{1}\left(m_{t}^{*}-m_{t}\right)+\beta_{2}\left(y_{t}^{*}-y_{t}\right)$

To estimate (11), several estimation techniques are employed. Using OLS, fully modified OLS (FMOLS) (Phillips and Hansen, 1990), dynamic OLS (Saikkonen, 1991; Stock \& Watson, 1993), and the Johansen (1988; 1991) multivariate maximum likelihood estimation (JOH-ML), we estimate the co-integrating relationship that the long-run monetary model posits. It is known that OLS estimates of $\beta_{1}$ and $\beta_{2}$ are super-consistent but biased and not efficient asymptotically. However, the FMOLS, DOLS and JOH-ML estimates are asymptotically efficient and enable appropriate inferences about the parameters.

Further tests for co-integrating properties between $e_{t}, m_{t}^{*}-m_{t}$ and $y_{t}^{*}-y_{t}$ include using tests from Philips and Ouliaris (1990), Hansen (1992) and Shin (1994) with single-equation procedures and the Johansen (1988; 1991) system-based approach. These tests are 


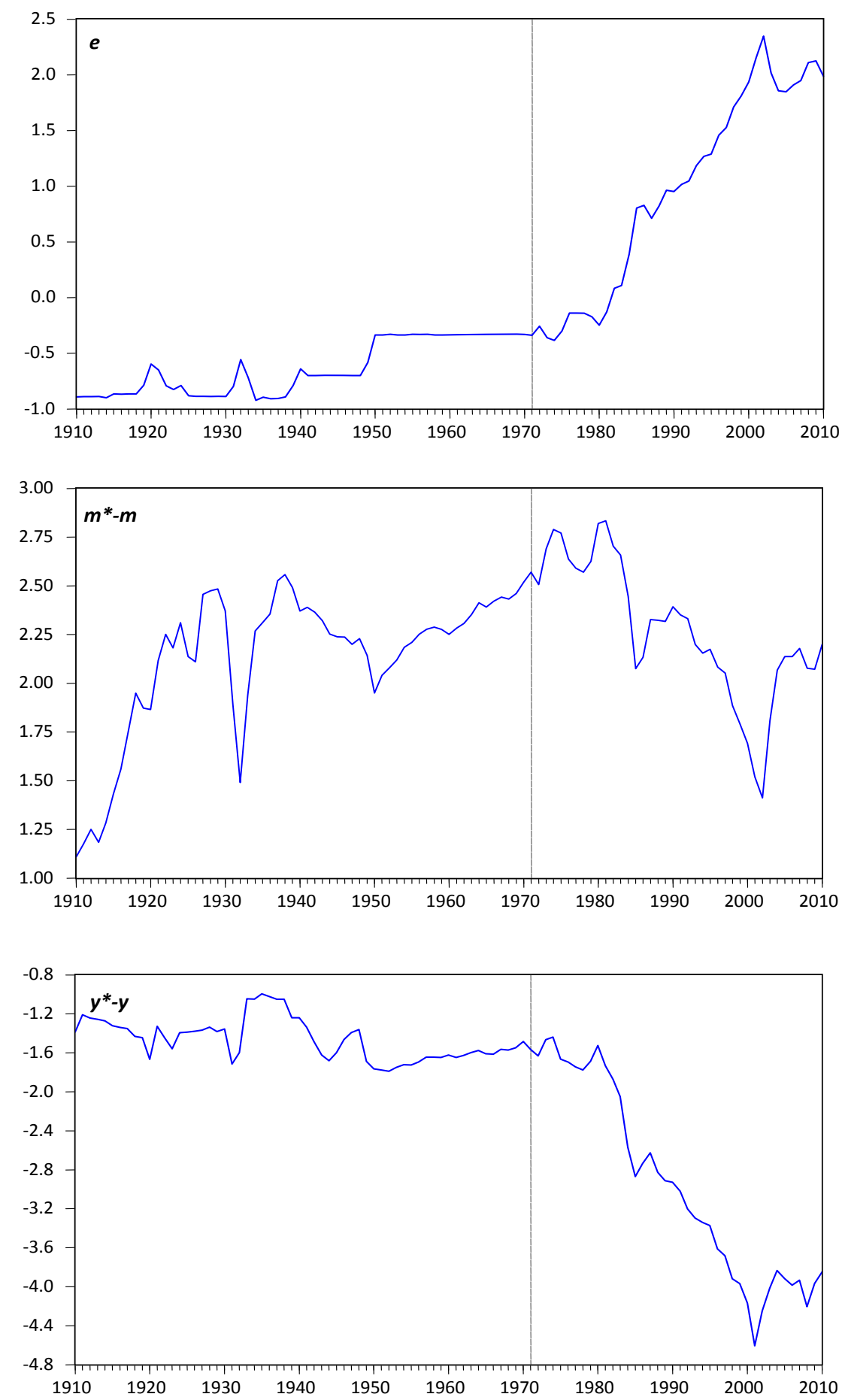

Figure 1. Time-series plots of $e_{t^{\prime}} m_{t}^{*}-m_{t}$ and $y_{t}^{*}-y_{t}$ for 101 years 
Table 1. Unit Root tests Results

\begin{tabular}{|c|c|c|c|c|c|}
\hline \multirow[b]{2}{*}{ (1) } & \multicolumn{5}{|c|}{ Test and Decision } \\
\hline & $(2)$ & (3) & (4) & (5) & (6) \\
\hline Variables & $D F G L S_{\mu}^{a}$ & $D F G L S_{\tau}^{a}$ & $M Z_{\mu}^{b}$ & $M Z_{\tau}^{b}$ & Decision \\
\hline$e$ & 1.20 & -1.04 & 1.92 & -3.02 & $I(1)$ \\
\hline$d(e)$ & $-4.53^{* * *}$ & $-4.93 * * *$ & $-30.65^{* * *}$ & $-45.81^{* * *}$ & $I(0)$ \\
\hline$m^{*}-m$ & -0.52 & -1.2 & -0.84 & -3.44 & $I(1)$ \\
\hline$d\left(m^{*}-m\right)$ & $-5.30^{* * *}$ & $-6.33^{* * *}$ & $-43.57^{* * *}$ & $-45.36^{* * *}$ & $I(0)$ \\
\hline$y^{*}-y$ & 0.66 & -1.18 & -0.74 & -2.90 & $I(1)$ \\
\hline$d\left(y^{*}-y\right)$ & $-1.94^{*}$ & $-8.04^{* * *}$ & $-5.76^{*}$ & $-21.95^{* *}$ & $I(0)$ \\
\hline \multicolumn{6}{|c|}{$\begin{array}{l}\text { Notes } \\
\text { *, }^{* *},{ }^{* *} \text { indicate the } 10 \%, 5 \% \text { and } 1 \% \text { significance level, respectively. } \\
\text { a } \mathrm{Ng} \text { and Perron (2001) one-sided test of } \boldsymbol{H}_{0} \text { : Nonstationarity; } 10 \%, 5 \% \text { and } 1 \% \text { critical values equal }-1.62,-1.98 \text { and }-2.58 \text {, re- } \\
\text { spectively; when a linear trend is included the } 10 \%, 5 \% \text { and } 1 \% \text { critical values equal }-2.62 .-2.91 \text { and }-3.42, \text { respectively. } \\
\text { b } \mathrm{Ng} \text { and Perron (2001) one-sided test of } \boldsymbol{H}_{0} \text { : Nonstationarity; } 10 \%, 5 \% \text { and } 1 \% \text { critical values equal }-5.70,-8.10 \text { and }-13.80 \text {, } \\
\text { respectively; when a linear trend is included the } 10 \%, 5 \% \text { and } 1 \% \text { critical values equal }-14.2,-17.3 \text { and }-23.8 \text {, respectively. }\end{array}$} \\
\hline
\end{tabular}

constituting the simple monetary model have a unit root and should therefore be $I(1)$. To confirm these results, the same testing procedures are applied to the variables in differences. The null of non-stationarity is rejected for all three variables, regardless of the inclusion of a linear trend in the specification. Again, these results indicate that all three variables constituting the simple monetary model are $I(1)$.

Based on the test results of the unit roots reported in Table 1, it is concluded that all three of the variables $e_{t}, m_{t}^{*}-m_{t}$ and $y_{t}^{*}-y_{t}$ are $I(1)$ for South Africa. These supporting results inform for further testing whether the long-run monetary model holds using co-integrating techniques.

\subsubsection{Co-integration test results}

As required by the long-run monetary model, the next section proceeds to test for a co-integrating relationship between the three components of the posited model.

Based on the unit root test results obtained and reported in Table 1, the following co-integrating relationship is estimated for South Africa:

$e_{t}=\beta_{0}+\beta_{1}\left(m_{t}^{*}-m_{t}\right)+\beta_{2}\left(y_{t}^{*}-y_{t}\right)$.
The reported co-integrating coefficient estimates are found in Table 2 below. We also estimated the cointegrating relationship including a trend. The results obtained were very similar to those reported in the text that excludes a trend. Furthermore, because the deviation of the exchange rate from the monetary fundamental did not exhibit a strong trend, in turn confirmed by formal statistical tests of the significance of the linear trend in the co-integrating vector, we decided to exclude these results to save space. These results are, however, available upon request from the authors. Table 2 includes the OLS, FMOLS, DOLS and JOHML estimates for both $\beta_{1}$ and $\beta_{2}$. Akin to Rapach and Wohar (2002), the application in Hansen (1992) is followed, and the quadratic kernel is used along with the Andrews (1991) automatic bandwidth selector with Andrews and Monohan (1992) pre-whitening when computing FM-OLS estimates. From Stock and Watson (1993), the number of leads and lags in the DOLS estimator are set to two, and for robust standard errors, an autoregressive computational procedure is used.

A Stock and Watson (1993) Wald test (SW-Wald) that tests the joint hypothesis of $\beta_{1}=1$ and $\beta_{2}=-1$ is reported. This restriction is implied by the simple 
Table 3. Co-integration test Results: $e_{t}=\beta_{0}+\beta_{1}\left(m_{t}^{*}-m_{t}\right)+\beta_{2}\left(y_{t}^{*}-y_{t}\right)$

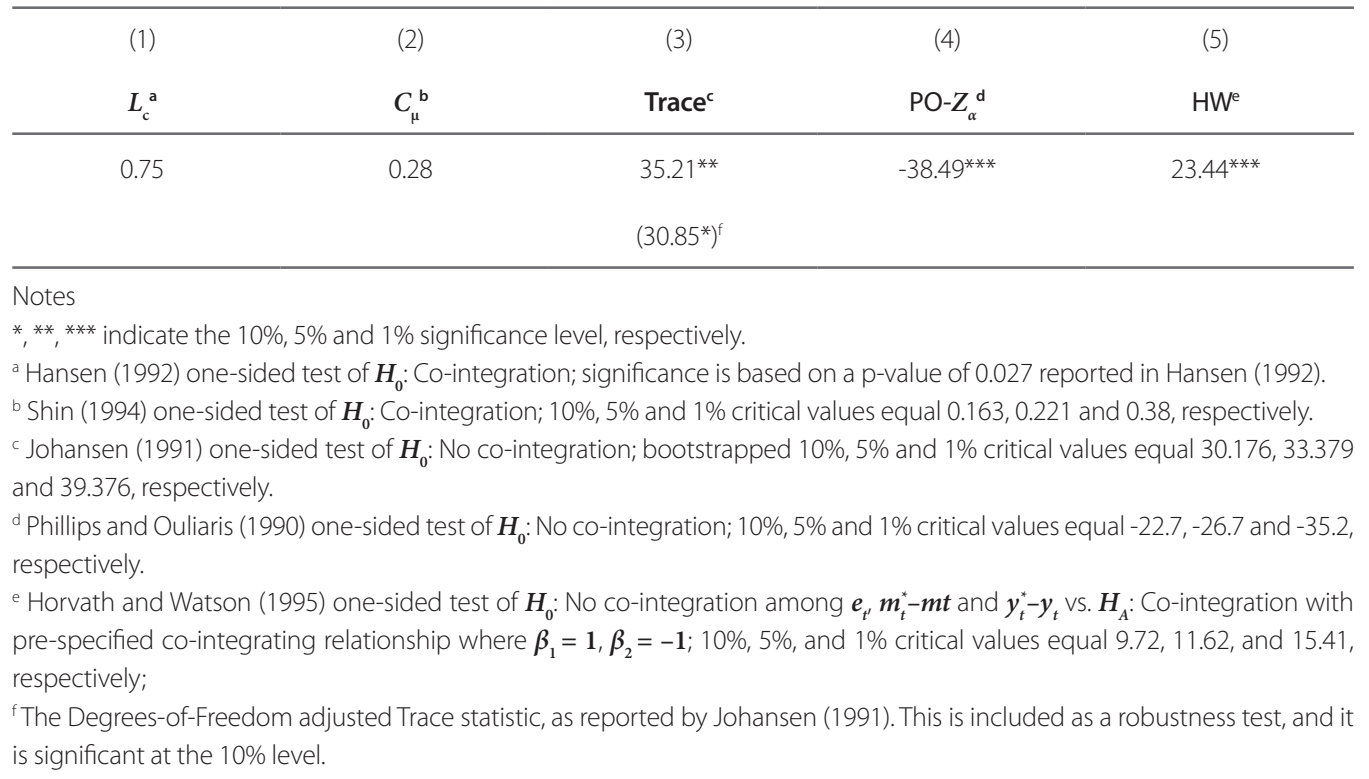

The null of co-integration resonates with this paper's emphasis, which indicates that the long-run monetary model holds. Based on FMOLS residuals, the $L_{c}$ statistic of Hansen (1992) is reported in Column 1 of Table 3, while Shin's (1994) $C_{\mu}$ statistic is based on DOLS residuals and is reported in Column 2 of Table 3.

For both the Hansen (1992) and Shin (1994) tests, based on the FMOLS and DOLS estimates of both parameters, respectively, the null of co-integration is rejected at conventional significance levels. From the results reported in Table 2, it is clear that the FMOLS and DOLS estimates for $\beta_{1}$ specifically do not coalesce with the theoretical expectations. These theoretically inconsistent results for $\beta_{1}$ may lead to incorrectly rejecting the null of co-integration. However, it is also possible that the lack of co-integration could also lead to theoretically inconsistent results. Evidently, this direction of causality is not clear. Hence, we rely on three additional tests of co-integration.

In contrast, the trace test of Johansen (1991) based on the maximum likelihood estimates of the parameters rejects the null of no co-integration even when the degreesof-freedom adjustment is considered. This result is further supported by the Phillips and Ouliaris (1990) test based on the OLS estimates of the parameters that strongly re- ject the null of no co-integration. The potentially more powerful Horvath and Watson (1995) multivariate test of co-integration also rejects the null of no co-integration. Although the five tests reported in Table 3 provide mixed support for the posited long-run co-integrating relationship of the simple monetary model for South Africa, three of the five tests strongly support the notion of long-run co-integration between nominal exchange rates and monetary fundamentals of the US and South Africa. We also tested the monetary model using broader measures of money, namely $M_{1}, M_{2}$ and $M_{3}$. Because data on these aggregates are only available since 1965, our analysis covered the period between 1965 and 2010. We found that with $M_{1}$, there exists strong evidence of cointegration; however, the theoretical restrictions do not hold. The $M_{2}$ and $M_{3}$ differentials were both found to be $I(0)$; hence, we tested the monetary model only based on the output differential, and no evidence of co-integration could be detected over this short-span of data. Details of these results are available upon request from the authors.

\subsection{The vector error-correction model}

To understand the adjustment process between nominal exchange rates and monetary fundamentals and how long-run exchange equilibrium is restored, the follow- 
ing vector error-correction model (VECM) is estimated for $e_{t}$ and $f_{t}$, with $f_{t}=\left(m_{t}^{*}-m_{t}\right)-\left(y_{t}^{*}-y_{t}\right)$ :

$\Delta e_{t}=\phi_{0}+\sum_{i=1}^{p} \phi_{1 i} \Delta e_{t-i}+\sum_{i=1}^{p} \phi_{2 i} \Delta f_{t-i}+\lambda_{1} E C M_{t-1}+\varepsilon_{1 t}$

$\Delta f_{t}=\delta_{0}+\sum_{i=1}^{p} \delta_{1 i} \Delta e_{t-i}+\sum_{i=1}^{p} \delta_{2 i} \Delta f_{t-i}+\lambda_{2} E C M_{t-1}+\varepsilon_{2 t}$

where the error-correction mechanism (ECM) is essentially the deviation of the nominal exchange rate from its long-run equilibrium level. Using (12) and (13), the adjustment process between nominal exchange rates and monetary fundamentals can be mapped out to better understand whether nominal exchange rates or monetary fundamentals adjust to restore the long-run exchange rate equilibrium. A priori, we expect that the monetary fundamentals, not the exchange rate, adjust to restore the long-run equilibrium exchange rate, such that there are no weakly exogenous variables in the system.

The $\phi_{i} \mathrm{~s}$ and $\delta_{i} \mathrm{~s}$ are the short-run adjustment parameters, while the $\lambda_{i} \mathrm{~s}$ are the long-run adjustment parameters coming from the long-run co-integrating relationship. The OLS estimates of the error-correction coefficients $\lambda_{1}$ and $\lambda_{2}$, which determine the adjustment process back to the long-run equilibrium, are -0.087 (0.03) and $0.096(0.04)$, respectively, with standard errors in parenthesis. These estimates are significant at conventional levels.

For South Africa, the results support the underlying assumption that the long-run monetary model is stable and that there exists a co-integrating relationship between nominal exchange rates and monetary fundamentals. Furthermore, it is found that both the nominal exchange rate and the monetary fundamentals adjust to restore the long-run equilibrium exchange rate. This implies that neither the nominal exchange rate nor the monetary fundamentals in South Africa are weakly exogenous relative to the long-run equilibrium exchange rate, which may justify the potential of using monetary fundamentals to accurately forecast exchange rate deviations, especially over longer horizons.

\section{Forecasting}

The superiority of the random walk model over an array of monetary models in forecasting out-of-sample, as reported in Meese and Rogoff (1983), deserves some mention. First, because a random walk model cannot claim to be an economic model, it would therefore fail all three principal economic model criteria: to explain, to predict and to inform in some sense on policies. Second, the forecasting horizon should be appealing and contextual.

Mark (1995), Mark and Sul (2001) and Rapach and Wohar (2002) at least exacted some credibility for the forecasting ability of the monetary model over longer forecasting horizons. Using the long span of data for South Africa, the forecasting performance of the simple monetary model posited here is compared with the forecasting performance of a random walk model with a drift.

The recursive out-of-sample forecast is updated with information from every attained forecasting period through period $t_{0}<T$, where $t_{0}$ is the starting period and $T$ is the available sample size. Following Mark (1995), the difference between the predicted value and the actual value of the nominal exchange rate is estimated and then compared with those estimated by a random walk model over the same horizon.

The tests for the out-of-sample one-year-ahead forecasting results are reported in Table 4.

The different forecasts are compared using an array of tests proposed in Clark and McCracken (2001). These tests include Theil's U-test, the Diebold and Mariano (1995) test (MSE-F), the West (1996) test (MSE-T), the ENC-T test of Harvey, Leybourne and Newbold (1998), the ENC-REG test of Ericsson (1992) and the ENCNEW test developed by Clark and McCracken (2001). For a more comprehensive survey of the different test statistics, see Clark and McCracken (2001).

Theil's U-ratio of 0.94 indicates that the prediction error from the monetary model is smaller than that of the random walk model, which implies that the simple monetary model has better forecasting performance at longer horizons than a random walk with drift.

Based on extensive simulations performed by Clark and McCracken (2001), the ranking power of the tests takes the following order:

\section{ENC-NEW > MSE-F, ENC-T, ENC-REG > MSE-T.}

For both the Diebold and Mariano (1995) and the West (1996) tests, the null hypothesis that the mean square prediction error (MSE) of the random walk model equals the MSE of the monetary fundamentals model is rejected at conventional levels in favor of the alternative hypothesis, which states that the MSE of 
Table 4. Out-of-sample one-horizon ahead forecasting Results

\begin{tabular}{lcccccc}
\hline$(1)$ & $(2)$ & $(3)$ & $(4)$ & $(5)$ & $(6)$ & $(7)$ \\
Forecast period & $\mathrm{U}^{\mathrm{a}}$ & $\mathrm{M}-\mathrm{F}^{\mathrm{b}}$ & $\mathrm{M}-\mathrm{T}^{\mathrm{c}}$ & $\mathrm{E}-\mathrm{NEW}$ & $\mathrm{E}-\mathrm{T}^{\mathrm{e}}$ & $\mathrm{E}^{\mathrm{R}}$ \\
\hline $1960-2010$ & 0.94 & $7.12^{* * *}$ & $1.57^{* * *}$ & $4.23^{* * *}$ & $1.77^{* *}$ & $3.87^{* * *}$ \\
\hline
\end{tabular}

Notes

$*^{*},{ }^{* * * *}$ indicate the $10 \%, 5 \%$ and $1 \%$ significance level, respectively.

${ }^{a} U$ is Theil's ratio of the RMSE $E_{M F} / R_{M S E}$ which measures the relative size of the prediction error from the monetary model with the random walk model and if $\boldsymbol{U}<\mathbf{1}$, the monetary model outperforms the random walk model; the initial recursive forecast use the first 50 years of the sample.

${ }^{\mathrm{b}}$ One-sided test of $\boldsymbol{H}_{0}: M S E_{R W}=\boldsymbol{M S E _ { M F }}$ vs. $\boldsymbol{H}_{I}: \boldsymbol{M S E}_{R W}>\boldsymbol{M S E _ { M F }}$ McCracken (1999); $10 \%, 5 \%$ and $1 \%$ critical values equal 0.751 , 1.548 and 3.584 , respectively.

' One-sided test of $\boldsymbol{H}_{0}: M S E_{R W}=M S E_{M F}$ vs. $\boldsymbol{H}_{1}: M S E_{R W}>M S E_{M F^{\prime}}$ McCracken (1999); $10 \%, 5 \%$ and $1 \%$ critical values equal 0.443 , 0.771 and 1.436 , respectively.

d One-sided test of $\boldsymbol{H}_{\mathbf{0}}$ : Forecast encompassing with RW encompassing MF; Clark and McCracken (2001); 10\%, 5\% and 1\% critical values equal $0.984,1.584$ and 3.209 , respectively.

e One-sided test of $\boldsymbol{H}_{\mathbf{0}}$ : Forecast encompassing with RW encompassing MF; Clark and McCracken (2001); 10\%, 5\% and 1\% critical values equal $0.955,1.331$ and 2.052 , respectively.

the random walk model is bigger than the MSE of the monetary fundamentals model. Moreover, based on more recent theoretical work by Clark and McCracken (2001), which tests for forecasting that encompasses the nested models under the null hypothesis, the notion that random walk models encompass all of the information contained in the forecasting of the monetary model is rejected consistently. These results indicate that, for South Africa and the US, the forecasting ability of the simple monetary model outperforms a random walk model with drift.

Therefore, there is considerable evidence that monetary fundamentals should help predict the nominal exchange rate in South Africa. Based on the results obtained from the VECM analysis, this should not be surprising.

\section{Conclusion}

Evidence in favor of the monetary model of exchange rate determination for the South African Rand is, at best, mixed. A co-integrating relationship between the nominal exchange rate and fundamentals forms the basis of the monetary model. With the econometric literature suggesting that it is the span of the data, not the frequency, that determines the power of the co-integration tests, we decided to test the longrun monetary model of exchange rate determination for the South African Rand relative to the US Dollar, using annual data from 1910 to 2010. An additional motivation is that most of the studies conducted on South Africa use a short span of data, covering only the post-Bretton Woods era.

The results provide some support for the monetary model in the sense that long-run co-integration is found between the nominal exchange rate and the output and money supply deviations. However, the theoretical restrictions required by the monetary model are rejected. An adjustment process, through which the long-run equilibrium of the nominal exchange rate is restored, is identified through the estimation of a vector error-correction model. In the presence of a deviation from the long-run equilibrium, both the nominal exchange rate and the monetary fundamentals adjust to restore the steady-state.

Even though the evidence in favor of the monetary model is not strong because it is difficult to justify the theoretical restrictions, the monetary model is found to outperform the random walk model in an out-ofsample, one-year-ahead forecast comparison exercise. Overall, based on a long span of data, there is some evidence in favor of the monetary model in the very long term, especially in terms of forecasting, but the model has both low explanatory and predictive powers at shorter horizons, as depicted by earlier studies conducted using short spans of data. 


\section{References}

Ahking, F. W., \& Miller, S. M. (2004). A Comparison of the Stochastic Processes of Structural TimeSeries Exchange Rate Models, In A. Zellner \& F. C. Palm (Eds.). The structural econometric time-series analysis approach (pp. 405-418). Cambridge, UK: Cambridge University Press.

Andrews, D. W. K. (1991). Heteroskedasticity and autocorrelation consistent covariance matrix estimation. Econometrica, 59(3), 817-854.

Andrews, D. W. K., \& Monahan, J. C. (1992). An improved heteroskedasticity and autocorrelation consistent covariance matrix estimator. Econometrica, 60(4), 953-966.

Andrews, D. W. K. (1993). Tests for parameter instability and structural change with unknown change point. Econometrica, 61(4), 821-856.

Andrews, D. W. K., \& Ploberger, W. (1994). Optimal tests when a nuisance parameter is present only under the alternative. Econometrica, 62(6), 1383-1414.

Aron, J., Elbadawi, I., \& Kahn, B. (1997). Determinants of the real exchange rate in South Africa (Working Paper Series No. 97-16). Centre for the Study of African Economies, University of Oxford, London.

Brink, S., \& Koekemoer, R. (2000). The economics of exchange rates: a South African model. The South African Journal of Economic and Management Sciences, 3(1), 19-51.

Casteleijn, A. J. H. (1999, June). The viability of implementing an inflation targeting monetary policy framework in South Africa. South African Reserve Bank Quarterly Bulletin, 63-73.

Chinn, M. D. (1999). A monetary model of the South African Rand. The African Finance Journal, 1(1), 69-91.

Chinn, M. D., \& Meredith, G. (2005). Testing the uncovered interest parity at short and long horizons during the post-Bretton Woods era (Working Paper No. 11077). National Bureau of Economics Research.

Clark, T. E., \& McCracken, M. W. (2001). Tests of equal forecast accuracy and encompassing for nested models. Journal of Econometrics, 105(1), 85-110.

Dickey, D. A., \& Fuller, W. A. (1979). Distribution of the estimators for autoregressive time series with a unit root. Journal of the American Statistical Association, 74(366), 427-431.
Diebold, F. X., \& Mariano, R. S. (1995). Comparing predictive accuracy. Journal of Economics and Business Statistics, 13(3), 253-263.

Dube, S. (2008). Stock prices and the exchange rate in a monetary model: an ARDL bounds testing approach using South African data. The African Finance Journal, 10(1), 1-27.

Ericsson, N. R. (1992). Cointegration, exogeneity and policy analysis: an overview. Journal of Policy Modeling, 14(3), 251-280.

Hakkio, C. S., \& Rush, M. (1991). Co-integration: how short is the long run? Journal of International Money and Finance, 10(4), 571-581.

Hansen, B. E. (1992). Tests for parameter instability in regressions with $I(1)$ processes. Journal of Business and Economic Statistics, 10(3), 321-335.

Harvey, D. I., Leybourne, S. J., \& Newbold, P. (1998). Tests for forecast encompassing. Journal of Business and Economic Statistics, 16(2), 254-259.

Hassan, S., \& Simione, F. (2011). Exchange rate determination under monetary policy rules in a financially underdeveloped economy: a simple model and application to Mozambique. Journal of International Development, forthcoming. New York: Wiley. (ERSA Working Paper 192.)

Horvath, M. T., \& Watson, M. W. (1995). Testing for cointegration when some of the cointegrating vectors are prespecified. Econometric Theory, 11(05), 984-1014.

Johansen, S. (1988). Statistical analysis of cointegrating vectors. Journal of Economic Dynamics and Control, 12(2-3), 231-254.

Johansen, S. (1991). Estimation and hypothesis testing of cointegration vectors in Gaussian vector autoregressive models. Econometrica, 59(6), 1551-1580.

Jonsson, G. (1999). Inflation, money demand and purchasing power parity in South Africa (Working paper No. 99/122). International Monetary Fund.

Kryshko, M. (2006). Nominal exchange rates and uncovered interest parity: non-parametric co-integration analysis (Unpublished article). Department of Economics, University of Pennsylvania.

Lacerda, M., Fedderke, J. W. \& Haines, L. M. (2010). Testing for purchasing power parity and uncovered interest parity in the presence of monetary and exchange rate regime shifts. The South African Journal of Economics, 78(4), 363-382. 
Ludi, K. L., \& Ground, M. (2006). Investigating the bank-lending channel in South Africa: a VAR approach (Working Paper No. 2006-04). Department of Economics, University of Pretoria.

Mark, N.C. (1995). Exchange rates and fundamentals: evidence on long-horizon predictability. American Economic Review, 85(1), 201-218.

Mark, N. C. \& Sul, D. (2001). Nominal exchange rates and monetary fundamentals: evidence from a small post-Bretton Woods panel. Journal of International Economics, 53(1), 29-52.

Meese, R. A., \& Rogoff, K. (1983). Empirical exchange rate models of the seventies: do they fit out of sample? Journal of International Economics, 14(12), 3-24.

Mokoena, T. M. (2007). Taking the puzzle out of the purchasing power parity puzzle: an application in respect of South Africa. The South African Journal of Economics, 75(1), 22-34.

Mokoena, T. M., Gupta, R., \& van Eyden, R. (2009a). Testing for fractional integration in SADC real exchange rates. The South African Journal of Economics, 77(4), 531-537.

Mokoena, T. M., Gupta, R., \& van Eyden, R. (2009b). Testing for PPP using SADC real exchange rates. The South African Journal of Economics, 77(3), 351-362.

Mokoena, T. M., Gupta, R., \& van Eyden, R. (2009c). Half-life deviations from PPP in the SADC. Applied Econometrics and International Development, 9(1), 141-148.

Moll, P. G. (1999). Money, interest rates, income and inflation in South Africa. The South African Journal of Economics, 67(1), 34-64.

Moll, P. G. (2000). The demand for money in South Africa: parameter stability and predictive capacity. The South African Journal of Economics, 68(2), 190-211.

Nell, K. S. (2003). The stability of M3 money demand and monetary growth targets: the case of South Africa. Journal of Development Studies, 39(3), 155-180.

Ng, S., \& Perron, P. (2001). Lag length selection and the construction of unit root tests with good size and power. Econometrica, 69(6), 1519-1554.

Otero, J., \& Smith, J. (2000). Testing for co-integration: power versus frequency of observation - further Monte-Carlo results. Economics Letters, 67(1), 5-9.
Phillips, P. C. B. (1994). Some exact distribution theory for maximum likelihood estimators for cointegrating coefficients in error correction models. Econometrica, 62(1), 73-93.

Phillips, P. C. B., \& Hansen, B. E. (1990). Statistical inference in instrumental variables regression with I(1) processes. Review of Economic Studies, 57(1), 99-125.

Phillips, P. C. B., \& Ouliaris, S. (1990). Asymptotic properties of residual based tests for cointegration. Econometrica, 58(1), 165-193.

Phillips, P. C. B., \& Perron, P. (1988). Testing for a unit root in time series regression. Biometrika, 75(2), $335-346$.

Rapach, D. E., \& Wohar, M. E. (2002). Testing the monetary model of exchange rate determination: new evidence from a century of data. Journal of International Economics, 58(2), 359-385.

Rapach, D. E., \& Wohar, M. E. (2004). Testing the monetary model of exchange rate determination: a closer look at panels. Journal of International Money and Finance, 23(6), 867-895.

Saikkonen, P. (1991). Asymptotically efficient estimation of cointegrating regressions. Econometric Theory, 7(1), 1-21.

Shiller, R. J. \& Perron, P. (1985). Testing the random walk hypothesis: Power versus frequency of observation. Economics Letters 18(4), 381-386.

Shin, Y. (1994). A residual-based test of the null of cointegration against the alternative of no cointegration. Econometric Theory, 10(1), 91-115.

Sichei, M. M., Gebreselasie, T. G., \& Akanbi, O. A. (2005). An econometric model of the Rand-US Dollar nominal exchange rate. (Working Paper No. 2005-14). Department of Economics, University of Pretoria. Retrieved from http://www.esaf. org/internet/Publication.nsf/LADV/4EF3019B11 9A248142256FE3003D566E/\$File/OccPaper9.pdf

Sims, C.A. (1980). Macroeconomics and reality. Econometrica 48(1), 1-48.

Stock, J. H. \& Watson, M. W. (1993). A simple estimator of co-integrating vectors in higher order integrated systems. Econometrica 61(4), 783-820.

Van der Merwe, E. J. (1997). Exchange rate management policies in South Africa: recent experience and prospects (Occasional Paper No. 9). The South African Reserve Bank. 
Walsh, C.E. (2003). Monetary Theory and Policy. Cambridge, MA: MIT Press.

West, K. D. (1996). Asymptotic inference about predictive ability. Econometrica, 64(5), 1067-1084.

Ziramba, E. (2007). Measuring exchange market pressure in South Africa: an application of the Girton-Roper monetary model. The South African Journal of Economic and Management Sciences, 10(1), 89-98. 